\title{
Erratum to: Tandem Mass Spectrometry in the Technology of Determining Aralosides of Phytoadaptogene Compositions
}

I. V. Kazeev ${ }^{a}$ * *, O. A. Bocharova ${ }^{a}$, V. E. Shevchenko ${ }^{a}$, R. V. Karpova ${ }^{a}$, E. V. Bocharov ${ }^{a}$, E. V. Uyutova ${ }^{b}$, O. P. Sheychenko ${ }^{b}$, V. G. Kucheryanu ${ }^{c}$, and M. A. Baryshnikova ${ }^{a}$

${ }^{a}$ Blokhin National Medical Research Center of Oncology, Ministry of Health of the Russian Federation, Moscow, Russia

${ }^{b}$ All-Russian Research Institute of Medicinal and Aromatic Plants, Moscow, Russia

${ }^{c}$ Research Institute of General Pathology and Pathophysiology, Moscow, Russia *e-mail: ilya_delta@mail.ru

Submitted March 16, 2021; accepted for publication March 16, 2021

DOI: $10.1134 / \mathrm{S} 0040579521310018$

The last name of the eighth author should read as follows:

Kucheryanu

The original article can be found online at

https://doi.org/10.1134/S0040579520050334 